\title{
Impact of Physical Education Teachers' Training Programme on Management of Perfectionism
}

\author{
Somnath Nandy ${ }^{1}$, Madhab Chandra Ghosh ${ }^{2}$, Samirranjan Adhikari ${ }^{3}$ \\ ${ }^{1}$ Research Scholar, Department of Physical Education, University of Kalyani, Kalyani, Nadia, W. B., India. \\ ${ }^{2}$ Associate Professor, Department of Physical Education, University of Kalyani, Kalyani, Nadia W.B., India. \\ ${ }^{3}$ Assistant Professor in Psychology, Shimurali Sachinandan College of Education, Nadia, W.B., India.
}

\begin{abstract}
Perfectionism is a personality trait characterized by striving for flawlessness and setting excessively high standards for performance, accompanied by tendencies toward overly critical evaluations of one's behaviour. In physical education teachers training curriculum there is ample scope of rigorous physical activity as well as educational and mental exercise; so the main goal of the present study was to ascertain the impact of this training on management of Perfectionism. To measure Perfectionism of prospective teachers in physical education, Perfectionistic Self-Presentation Scale (PSPS) was administered on students of B.P.Ed. Course in three different phases during the academic session 2006 - 2007. The mean of the $1^{\text {st }}$ Factor of PSPS (i.e., Perfectionistic Self-Promotion: proclaiming and displaying one's perfection) scores of $1^{\text {st }}, 2^{\text {nd }}$ and $3^{\text {rd }}$ phase of testing were 50.69, 41.82 and 25.22 respectively. In $2^{\text {nd }}$ Factor of PSPS: (i.e., Non-display of Imperfection: concealing and avoiding behavioral demonstration of one's imperfection) these were 52.90, 44.65 and 28.38 respectively. In $3^{\text {rd }}$ Factor (i.e., Non-disclosure of Imperfection: evading and avoiding verbal admission of one's imperfection) the means were $54.23,47.64$ and 31.14 respectively. We may conclude that the physical education teachers' training programme (B.P.Ed. Course) have positive impact on management of Perfectionism.
\end{abstract}

Key words: Likert type scale, Management of Perfectionism, Perfectionism, Perfectionistic Self-Presentation Scale (PSPS), Physical Education Teachers' Training Programme,

\section{Introduction}

Perfectionism is traditionally viewed as an enduring personality trait (Hewitt \& Flett, 1991) [1]. There are numerous definitions of perfectionism in the general psychology literature (Flett \& Hewitt, 2002) [2]. Theorists concur that the setting of high performance standards is a central feature of the construct (Frost, Marten, Lahart, \& Rosenblate, (1990); Hamachek, (1978) ; Hewitt \& Flett, (1991) [3], [4], [1]. These standards can be evaluated according to intrapersonal and interpersonal criteria. Consequently, many researchers view perfectionism as a multidimensional construct (Blatt, 1995; Flett \& Hewitt, 2002) [5] [2].

In sports, some researchers see perfectionism as an adaptive trait that helps to achieve elite performance (Gould, Dieffenbach, \& Moffett, 2002) [6]. Other researchers, however, see perfectionism as a maladaptive trait that hinders, rather than helps athletic performance (Flett \& Hewitt, 2005) [7]. Consequently, athletes may face what Hewitt and Flett call the "perfectionism paradox." Although in many sports athletes are expected to deliver perfect performance outcomes, perfectionism in athletes has been shown to be related to characteristics that may undermine performance, particularly competitive anxiety. Consequently, perfectionism in athletes may prevent the very outcomes that it seeks to promote (Flett \& Hewitt, 2005) [7].

However, perfectionism is multidimensional and multifaceted, and only some dimensions and facets are clearly negative, harmful, and maladaptive, while others may be positive, benign, and adaptive (Chang, 2003; Enns \& Cox, 2002) [8] [9]. Moreover, research has suggested that two major dimensions of perfectionism be differentiated (Stoeber \& Otto, 2006) [10]: a dimension which has been described as positive, healthy, or adaptive perfectionism and a dimension which has been described as neurotic, unhealthy, or maladaptive perfectionism (Rice \& Preusser, 2002; Stumpf \& Parker, 2000; Terry-Short, Owens, Slade \& Dewey, 1995) [11] [12] [13]. The negative dimension of perfectionism subsumes those facets of perfectionism that relate to Perfectionistic concerns such as concern over mistakes, doubts about actions, feelings of discrepancy between expectations and results, and negative reactions to mistakes.

So far, three studies have investigated the relationship between perfectionism and competitive anxiety in athletes (Frost \& Henderson, 1991 ; Hall, Kerr, \& Matthews, (1998) ; Koivula, Hassmén, \& Fallby, (2002) [14], [15], [16]. Frost and Henderson (1991) [14] investigated perfectionism and competitive anxiety in female college ahletes. Results showed that overall perfectionism showed a positive correlation with competitive anxiety and an inverse correlation with self confidence in competitions. When the facets of perfectionism were inspected, however, only concern about mistakes (a facet of negative perfectionism) was positively correlated with anxiety and inversely with self-confidence. Personal standards (a facet of positive perfectionism) were 
unrelated to anxiety and self-confidence. Hall et al. (1998) [15] investigated perfectionism and competitive anxiety in high school athletes who were to compete in a cross-country meet, measuring cognitive anxiety, somatic anxiety, and self-confidence at four points of time: one week, two days, one day, and 30 minutes before competition. At all points, overall perfectionism showed a positive correlation with cognitive anxiety. At the facet level, however, only concern over mistakes showed a positive correlation with cognitive anxiety. Personal standards did not show a positive correlation with cognitive anxiety (except 30 minutes before competition), but showed a positive correlation with self-confidence at all points of time (including 30 minutes before competition). Finally, Koivula et al. (2002) [16] investigated competitive anxiety in Swedish elite athletes comparing different groups of perfectionists.

From the perspective of maladaptive functioning, perfectionism dimensions have been associated with(i) heightened anger (Hewitt \& Flett, 1991) [1], (ii) depression (Frost et al., 1990) [3] and (iii) eating disorders symptoms (Hewitt, Flett, \& Ediger, 1995) [17].

Perfectionistic self-presentation is a pervasive and stable interpersonal style, which can be regarded as a component of personality. This can be conceptualized as a stylistic trait and it involves an expression of perfectionist behaviour. This aspect of the perfectionism construct is related to the extent that they are all part of a broader perfectionism construct. However, Perfectionistic self-presentation also has some clear distinguishing features. Whereas the trait dimensions reflect, a need to be perfect, Perfectionistic self-presentation reflects a need simply to appear to be perfect.

\section{Objective of the Study}

Physical education takes a crucial role in general education. However, a few numbers of studies are there to probe into the impact of physical education on various psychosocial and moral developments. Again, there is much theoretical speculation and empirical research about the effect of physical education on somatic and mental developmental; but the impact physical education on spiritual development has yet to be probed into. The present study is designed to explore the impact of B. P. Ed. Course on Development of Achievement Motivation.

\section{Method}

The present study was carried out through the method of experimental research with one-group pre-test - post-test design. The details regarding research design, sample, tools, procedure of data collection and statistical technique are reported herewith.

\subsection{Paired Samples Design:}

Paired samples (also called dependent samples) are samples in which natural or matched couplings occur. In paired samples, each data point in one sample is matched to a unique data point in the second sample. An example of a paired sample is a pre-test - post-test study design in which factors are measured before and after an intervention. Paired samples may also be achieved by matching individuals on personal characteristics such as age and gender.

\subsection{Variables:}

Following were the variables in the study. Independent Variable - Physical education teachers training programme (B.P.Ed. Course) was the independent variable. Dependent Variables - Perfectionism was the dependent variable.

\section{3 Demographic Data of the Experimental Group:}

Demographic data of the subjects in experimental group are presented in the following tables.

\subsubsection{Institute wise Distribution:}

Table - 1: Institute wise Frequency Distribution

\begin{tabular}{|c|c|c|c|}
\hline Institute & Frequency & Percent & $\begin{array}{c}\text { Cumulative } \\
\text { Percent }\end{array}$ \\
\hline Banipur $^{* *}$ & 118 & 59.0 & 59.0 \\
\hline Kalyani $^{* *}$ & 82 & 41.0 & 100.0 \\
\hline Total & 200 & 100.0 & \\
\hline
\end{tabular}

From Table- 1 it is clear that the percentage of participants from Banipur" was 59 and Kalyani** was 41. 3.3.2 Educational Qualification wise Distribution:

Table - 2: Educational Qualification wise Frequency Distribution

\begin{tabular}{|l|l|l|l|l|l|l|}
\hline & B.A. & B.Sc. & B.Com. & M.A. & M.Sc. & M.Com. \\
\hline
\end{tabular}

\footnotetext{
* Post Graduate Training College for Physical Education, Banipur, North 24-Parganas, West Bengal, India

** Department of Physical Education, University of Kalyani, Kalyani, Nadia, West Bengal, India 
Impact Of Physical Education Teachers' Training Programme On Management Of Perfectionism

\begin{tabular}{|c|c|c|c|c|c|c|c|c|c|c|c|c|}
\hline \multirow{2}{*}{ Institute } & \multicolumn{3}{|l|}{} & \multicolumn{3}{|c|}{} & \multicolumn{3}{|c|}{} & & & \\
\cline { 2 - 15 } & $\mathrm{M}$ & $\mathrm{F}$ & $\mathrm{M}$ & $\mathrm{F}$ & $\mathrm{M}$ & $\mathrm{F}$ & $\mathrm{M}$ & $\mathrm{F}$ & $\mathrm{M}$ & $\mathrm{F}$ & $\mathrm{M}$ & $\mathrm{F}$ \\
\hline Banipur & 59 & 12 & 10 & 4 & 23 & 3 & 4 & 1 & 1 & 0 & 1 & 0 \\
\hline Kalyani & 41 & 14 & 5 & 3 & 11 & 0 & 2 & 2 & 1 & 1 & 2 & 0 \\
\hline Total & 100 & 26 & 15 & 7 & 34 & 3 & 6 & 3 & 2 & 1 & 3 & 0 \\
\hline$\%$ & 62.5 & 65 & 9.375 & 17.5 & 21.25 & 7.5 & 3.75 & 7.5 & 1.25 & 2.5 & 1.875 & 0 \\
\hline
\end{tabular}

Here $\mathrm{M}=$ "Male" and $\mathrm{F}=\mathrm{e}$ "Female".

3. 3.3 Gender wise Distribution:

Table - 3: Gender wise Frequency Distribution

\begin{tabular}{|c|c|c|c|}
\hline Gender & Frequency & Percent & $\begin{array}{c}\text { Cumulative } \\
\text { Percent }\end{array}$ \\
\hline Female & 40 & 20.0 & 20.0 \\
\hline Male & 160 & 80.0 & 100.0 \\
\hline Total & 200 & 100.0 & \\
\hline
\end{tabular}

From Table -3 it is revealed that there were $20 \%$ female and $80 \%$ male in the experimental group. In our institutions this picture is very common.

\section{3. 4 Age wise Distribution:}

Table - 4: Statistics of Age

\begin{tabular}{|c|c|}
\hline Statistics & Value \\
\hline $\mathrm{N}$ & 200 \\
\hline Mean & 24.07 \\
\hline Median & 24.00 \\
\hline Mode & 23 \\
\hline Std. Deviation & 2.09 \\
\hline Range & 10 \\
\hline Minimum & 20 \\
\hline Maximum & 30 \\
\hline
\end{tabular}

From Table -4 we can see that the mean age of the subjects was 24.07 years, ranging in age from 20 to 30 years. In question of age this was a homogeneous group.

Table - 5: Age wise Frequency Distribution

\begin{tabular}{|c|c|c|c|}
\hline Age & Frequency & $\%$ & $\begin{array}{l}\text { Cumulative } \\
\text { Percent }\end{array}$ \\
\hline 20 & 1 & 0.5 & 0.5 \\
\hline 21 & 8 & 4.0 & 4.5 \\
\hline 22 & 41 & 20.5 & 25.0 \\
\hline 23 & 49 & 24.5 & 49.5 \\
\hline 24 & 34 & 17.0 & 66.5 \\
\hline 25 & 21 & 10.5 & 77.0 \\
\hline 26 & 15 & 7.5 & 84.5 \\
\hline 27 & 6 & 3.0 & 87.5 \\
\hline 28 & 22 & 11.0 & 98.5 \\
\hline 29 & 2 & 1.0 & 99.5 \\
\hline 30 & 1 & 0.5 & 100.0 \\
\hline Total & 200 & 100.0 & \\
\hline
\end{tabular}

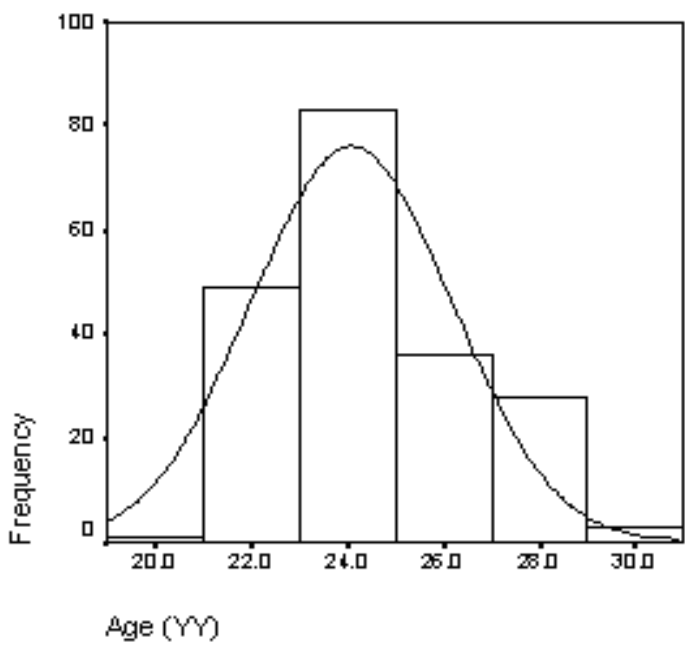

Fig. - 1: Age Wise Frequency Distribution

\section{4 Tool: Perfectionistic Self-Presentation Scale (PSPS; Hewitt et al., 2003):}

The PSPS is a 27-item multidimensional scale that assesses an individual's need to appear perfect to others (Hewitt et al., 2003) [18]. The PSPS has three subscales that assess Perfectionistic self- promotion (i.e., need to appear perfect to others; e.g., "I strive to look perfect to others"), Non-display of imperfection (i.e., need to avoid appearing imperfect to others; e.g., "I do not care about making mistakes in public," reverse-scored), and Nondisclosure of imperfection (i.e., need to avoid disclosing imperfections to others; e.g., "Admitting failure to others is the worst possible thing"). The first subscale is comprised of 10 items that assess a need to promote oneself as perfect to others and is labeled "Perfectionistic Self-Promotion" (i.e. proclaiming and 
displaying one's perfection), the second subscale is comprised of 10 items reflecting concerns over being seen publicly as behaving in a less-than-perfect manner by others and is labeled "Non-display of Imperfection" (i.e. concealing and avoiding behavioral demonstration of one's imperfection) and the remaining third subscale is comprised of 7 items reflecting non-admission of shortcomings and is labeled "Non-disclosure of Imperfection" (i.e. evading and avoiding verbal admission of one's imperfection).

\section{5Procedure of Data Collection:}

The tools were administered on the subjects in three different phases during the academic session 2006-07 and the responses were scored as per scoring procedure, prescribed in the manual.

The tool was administered in the following three phases -

a) In the first phase, the test was administered at the beginning of the B.P.Ed. course (in the $1^{\text {st }}$ week of July, 2006);

b) In the second phase the same test was administered in the middle of the course ( $3^{\text {rd }}$ week of November, 2006); and

c) In the final phase, the same test was administered at the completion of the course $\left(1^{\text {st }}\right.$ week of April, 2007, before study leave).

\section{6 Statistical Techniques:}

The descriptive as well as inferential statistics were found out by computing appropriate statistics with the help of SPSS-10.01 software. Here "Paired-Samples t Test" was preferred.

\section{Results}

Result of the present investigation is furnished in the following tables.

Table - 6: Paired Samples Statistics of Scores in PSPS of Different Phases of Study

\begin{tabular}{|c|c|c|c|c|}
\hline \multicolumn{2}{|c|}{ Variable } & Mean & $\mathbf{N}$ & $\square$ \\
\hline \multirow[t]{2}{*}{ Pair $_{1}$} & $1^{\text {st }}$ Factor $_{1}$ & 50.69 & 200 & 7.54 \\
\hline & $1^{\text {st }}$ Factor $_{2}$ & 41.82 & 200 & 6.18 \\
\hline \multirow[t]{2}{*}{ Pair $_{2}$} & $1^{\text {st }}$ Factor $_{2}$ & 41.82 & 200 & 6.18 \\
\hline & $1^{\text {st }}$ Factor $_{3}$ & 25.22 & 200 & 5.83 \\
\hline \multirow[t]{2}{*}{ Pair $_{3}$} & $1^{\text {st }}$ Factor $_{1}$ & 50.69 & 200 & 7.54 \\
\hline & $1^{\text {st }}$ Factor $_{3}$ & 25.22 & 200 & 5.83 \\
\hline \multirow[t]{2}{*}{ Pair $_{4}$} & $2^{\text {nd }}$ Factor $_{1}$ & 52.90 & 200 & 6.51 \\
\hline & $2^{\text {nd }}$ Factor $_{2}$ & 44.65 & 200 & 6.07 \\
\hline \multirow[t]{2}{*}{ Pair $_{5}$} & $2^{\text {nd }}$ Factor $_{2}$ & 44.65 & 200 & 6.07 \\
\hline & $2^{\text {nd }}$ Factor $_{3}$ & 28.38 & 200 & 5.52 \\
\hline \multirow[t]{2}{*}{ Pair $_{6}$} & $2^{\text {nd }}$ Factor $_{1}$ & 52.90 & 200 & 6.51 \\
\hline & $2^{\text {nd }}$ Factor $_{3}$ & 28.38 & 200 & 5.52 \\
\hline \multirow[t]{2}{*}{ Pair $_{7}$} & $3^{\text {rd }}$ Factor $_{1}$ & 54.23 & 200 & 6.32 \\
\hline & $3^{\text {rd }}$ Factor $_{2}$ & 47.64 & 200 & 5.99 \\
\hline \multirow[t]{2}{*}{ Pair $_{8}$} & $3^{\text {rd }}$ Factor $_{2}$ & 47.64 & 200 & 5.99 \\
\hline & $3^{\text {rd }}$ Factor $_{3}$ & 31.14 & 200 & 5.01 \\
\hline \multirow[t]{2}{*}{ Pair $_{9}$} & $3^{\text {rd }}$ Factor $_{1}$ & 54.23 & 200 & 6.32 \\
\hline & $3^{\text {rd }}$ Factor $_{3}$ & 31.14 & 200 & 5.01 \\
\hline
\end{tabular}

From Table -6 , it is observed that in $1^{\text {st }}$ Factor of PSPS (i.e., Perfectionistic Self-Promotion: proclaiming and displaying one's perfection) the means of scores of $1^{\text {st }}, 2^{\text {nd }}$ and $3^{\text {rd }}$ phase of testing were 50.69 , 41.82 and 25.22 respectively. In $2^{\text {nd }}$ Factor of PSPS: (i.e., Non-display of Imperfection: concealing and avoiding behavioral demonstration of one's imperfection) these were $52.90,44.65$ and 28.38 respectively. In $3^{\text {rd }}$ Factor (i.e., Non-disclosure of Imperfection: evading and avoiding verbal admission of one's imperfection) the means were $54.23,47.64$ and 31.14 . 


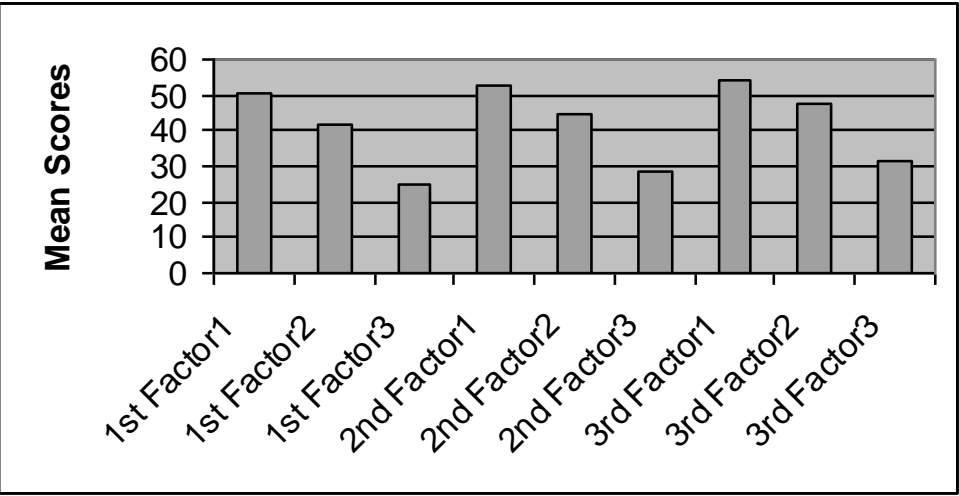

Fig. - 2: Mean of PSPS Facets Scores in Different Phases of Study

Table-7: Paired Samples Correlations among Scores in PSPS Facets of Different Phases of Study

\begin{tabular}{|c|c|c|c|c|}
\hline & Variable & $\mathbf{N}$ & Correlation & Sig. \\
\hline Pair $_{1}$ & $1^{\text {st }}$ Factor $_{1} \& 1^{\text {st }}$ Factor $_{2}$ & 200 & 0.103 & 0.145 \\
\hline Pair $_{2}$ & $1^{\text {st }}$ Factor $_{2} \& 1$ st Factor $_{3}$ & 200 & 0.155 & 0.028 \\
\hline Pair $_{3}$ & $1^{\text {st }}$ Factor $_{1} \& 1^{\text {st }}$ Factor $_{3}$ & 200 & -0.022 & 0.752 \\
\hline Pair $_{4}$ & $2^{\text {nd }}$ Factor $_{1} \& 2^{\text {nd }}$ Factor $_{2}$ & 200 & 0.203 & 0.004 \\
\hline Pair 5 & $2^{\text {nd }}$ Factor $_{2} \& 2^{\text {nd }}$ Factor $_{3}$ & 200 & 0.243 & 0.001 \\
\hline Pair $_{6}$ & $2^{\text {nd }}$ Factor $_{1} \& 2^{\text {nd }}$ Factor $_{3}$ & 200 & 0.154 & 0.030 \\
\hline Pair $_{7}$ & $3^{\text {rd }}$ Factor $_{1} \& 3^{\text {rd }}$ Factor $_{2}$ & 200 & 0.265 & 0.000 \\
\hline Pair $_{8}$ & $3^{\text {rd }}$ Factor $_{2} \& 3^{\text {rd }}$ Factor $_{3}$ & 200 & 0.276 & 0.000 \\
\hline Pair $_{9}$ & $3^{\text {rd }}$ Factor $_{1} \& 3^{\text {rd }}$ Factor $_{3}$ & 200 & 0.161 & 0.023 \\
\hline
\end{tabular}

From Table -7 , it is observed that the coefficients of correlations between the PSPS scores in the $1^{\text {st }}$ Factor $1^{\text {st }} \& 2^{\text {nd }}$ phase of testing was 0.103 , between the $2^{\text {nd }} \& 3^{\text {rd }}$ phase of testing was 0.155 and between the $1^{\text {st }} \& 3^{\text {rd }}$ phase of testing was -0.022 . It is observed that the coefficients of correlations between the PSPS scores in the $2^{\text {nd }}$ Factor $1^{\text {st }} \& 2^{\text {nd }}$ phase of testing was 0.203 , between the $2^{\text {nd }} \& 3^{\text {rd }}$ phase of testing was 0.243 and between the $1^{\text {st }} \& 3^{\text {rd }}$ phase of testing was 0.154 . It is also observed that the coefficients of correlations between the PSPS scores in the $3^{\text {rd }}$ Factor $1^{\text {st }} \& 2^{\text {nd }}$ phase of testing was 0.265 , between the $2^{\text {nd }} \& 3^{\text {rd }}$ phase of testing was 0.276 and between the $1^{\text {st }} \& 3^{\text {rd }}$ phase of testing was 0.161 . All correlations were highly (statistically) significant.

Table-8: Paired Samples Test of Scored in PSPS Facets of Different Phases of Study

\begin{tabular}{|c|c|c|c|c|c|c|}
\hline \multirow{2}{*}{\multicolumn{2}{|c|}{ Variable }} & \multicolumn{2}{|c|}{ Paired Differences } & \multirow{2}{*}{$\mathbf{t}$} & \multirow{2}{*}{ df } & \multirow{2}{*}{$\begin{array}{c}\text { Sig. } \\
\text { (2-tailed) }\end{array}$} \\
\hline & & Mean & S.D. & & & \\
\hline Pair $_{1}$ & $1^{\text {st }}$ Factor $_{1}-1^{\text {st }}$ Factor $_{2}$ & 8.87 & 9.24 & 13.576 & 199 & 0.000 \\
\hline Pair $_{2}$ & $1^{\text {st }}$ Factor $_{2}-1$ st Factor 3 & 16.60 & 7.81 & 30.047 & 199 & 0.000 \\
\hline Pair $_{3}$ & $1^{\text {st }}$ Factor $_{1}-1^{\text {st }}$ Factor $_{3}$ & 25.47 & 9.63 & 37.398 & 199 & 0.000 \\
\hline Pair $_{4}$ & $2^{\text {nd }}$ Factor $_{1}-2^{\text {nd }}$ Factor $_{2}$ & 8.25 & 7.95 & 14.678 & 199 & 0.000 \\
\hline Pair $_{5}$ & $2^{\text {nd }}$ Factor $_{2}-2^{\text {nd }}$ Factor $_{3}$ & 16.27 & 7.15 & 32.200 & 199 & 0.000 \\
\hline Pair $_{6}$ & $2^{\text {nd }}$ Factor $_{1}-2^{\text {nd }}$ Factor $_{3}$ & 24.52 & 7.86 & 44.093 & 199 & 0.000 \\
\hline Pair $_{7}$ & $3^{\text {rd }}$ Factor $_{1}-3^{\text {rd }}$ Factor $_{2}$ & 6.59 & 7.47 & 12.477 & 199 & 0.000 \\
\hline Pair $_{8}$ & $3^{\text {rd }}$ Factor $_{2}-3^{\text {rd }}$ Factor $_{3}$ & 16.49 & 6.67 & 34.992 & 199 & 0.000 \\
\hline Pair $_{9}$ & $3^{\text {rd }}$ Factor $_{1}-3^{\text {rd }}$ Factor $_{3}$ & 23.09 & 7.41 & 44.056 & 199 & 0.000 \\
\hline
\end{tabular}

From Table- 8 , it is observed that the mean of the $1^{\text {st }}$ Factor, $2^{\text {nd }}$ Factor and $3^{\text {rd }}$ Factor of PSPS scores of the B.P.Ed. Students decreased significantly as the course was advanced towards the completion.

\section{Discussion and Conclusion}

In the first phase of testing the Perfectionistic Self-Presentation Scale (PSPS) was administered at the beginning of the B.P.Ed. Course (in the $1^{\text {st }}$ week of July, 2006) the scores actually exhibited the entry behaviour (pre-test score). After some time of running the course in the second phase the same test was administered in $3^{\text {rd }}$ 
week of November, 2006. In the final phase, the same test was administered at the completion of the course $\left(1^{\text {st }}\right.$ week of April, 2007, before study leave). It is observed that the scores on all of the PSPS sub-scales (i.e., Perfectionistic Self-Promotion, Non-display of Imperfection and Non-disclosure of Imperfection) decreased as the course was advanced towards the completion. Perfectionistic Self-Promotion is actually the tendency of proclaiming and displaying one's perfection, Non-display of Imperfection is the tendency of concealing and avoiding behavioral demonstration of one's imperfection and Non-disclosure of Imperfection is the tendency of evading and avoiding verbal admission of one's imperfection. According to Hewitt, et al, (2003)[18] (a) Perfectionistic self-presentation are generally related to measures of anxiety and (b) that non-display of imperfection is especially linked to social measures of anxiety and (c) nondisclosure of imperfection uniquely predicts one non-socially based of anxiety. As per the progress of the B.P.Ed. Course the students' Perfectionistic self-presentation scores, non-display of imperfection scores and non-disclosure of imperfection scores were decreased. This fact transpires that B.P.Ed. course puts its impact on the management of general anxiety, social anxiety and non-socially based form of anxiety.

From the result it is clear that the scores in different factors of Perfectionistic Self Presentation Scale decreased gradually as the course advanced towards the completion. From this it may be concluded that the B.P.Ed. Course had a positive impact on management of perfectionism of the students. This in turn proves that B.P.Ed. Course may put its impact on the management of general anxiety, social anxiety and non-socially based form of anxiety.

\section{References}

[1] Hewitt, P. L., \& Flett, G. L. (1991). Perfectionism in the self and social contexts: Conceptualization, assessment, and association with psychopathology. Journal of Personality and Social Psychology, 60, 456-470.

[2] Flett, G. L., \& Hewitt, P. L. (2002). Perfectionism and maladjustment: An overview of theoretical, definitional, and treatment issues. In G. L. Flett, \& P. L. Hewitt (Eds.), Perfectionism: Theory, research, and treatment (pp. 5-31). Washington, DC: American Psychological Association.

[3] Frost, R. O., Marten, P., Lahart, C., \& Rosenblate, R. (1990). The dimensions of perfectionism. Cognitive Therapy and Research, $14,449-468$.

[4] Hamachek, D. E. (1978). Psychodynamics of normal and neurotic perfectionism. Psychology, 15, $27-33$.

[5] Blatt, S. J. (1995). The destructiveness of perfectionism: Implications for the treatment of depression. American Psychologist, 50, 1003-1020.

[6] Gould, D., Dieffenbach, K., \& Moffett, A. (2002). Psychological characteristics and their development in Olympic champions. Journal of Applied Sport Psychology, 14, 172-204.

[7] Flett, G. L., \& Hewitt, P. L. (2005). The perils of perfectionism in sports and exercise. Current Directions in Psychological Science, $14,14-18$.

[8] Chang, E. C. (2003). On the perfectibility of the individual: Going beyond the dialectic of good versus evil. In E. C. Chang \& L. J. Sanna (Eds.), Virtue, vice, and personality: The complexity of behavior (pp. 125-144). Washington, DC: American Psychological Association.

[9] Enns, M. W., \& Cox, B. J. (2002). The nature and assessment of perfectionism: A critical analysis. In G. L. Flett \& P. L. Hewitt (Eds.), Perfectionism: Theory, research, and treatment (pp. 33-62). Washington, DC: American Psychological Association.

[10] Stoeber, J., \& Otto, K. (2006). Positive conceptions of perfectionism: Approaches, evidence, challenges. Personality and Social Psychology Review, 10, 295-319.

[11] Rice, K. G., \& Preusser, K. J. (2002). The Adaptive/Maladaptive Perfectionism Scale. Measurement and Evaluation in Counseling and Development, 34, 210-222.

[12] Stumpf, H., \& Parker, W. D. (2000). A hierarchical structural analysis of perfectionism and its relation to other personality characteristics. Personality and Individual Differences, 28, 837-852.

[13] Terry-Short, L. A., Owens, R. G., Slade, P. D., \& Dewey, M. E. (1995). Positive and negative perfectionism. Personality and Individual Differences, 18, 663-668.

[14] Frost, R. O., \& Henderson, K. J. (1991). Perfectionism and reactions to athletic competition. Journal of Sport \& Exercise Psychology, 13, 323-335.

[15] Hall, H. K., Kerr, A. W., \& Matthews, J. (1998). Precompetitive anxiety in sport: The contribution of achievement goals and perfectionism. Journal of Sport \& Exercise Psychology, 20, 194-217.

[16] Koivula, N., Hassmén, P., \& Fallby, J. (2002). Self-esteem and perfectionism in elite athletes: Effects on competitive anxiety and self-confidence. Personality and Individual Differences, 32, 865-875.

[17] Hewitt, P. L., Flett, G. L., \& Ediger, E. (1995). Perfectionism trait and perfectionistic self-presentation in eating disorder attitudes, characteristics, and symptoms. International Journal of Eating Disorders, 18, 317-326

[18] Hewitt, P.L., Flett, G.L., Sherry, S.B., Habke, M., Parkin, M., Ediger, E., Fairlie, P., \& Stein, M.B. (2003). The interpersonal expression of perfection: perfectionistic self- presentation and psychological distress. Journal of Personality and Social Psychology, $84(6), 1303-1325$ 